\title{
Implementation of Unregistered Fiduciary Guarantee Reviewed From Law Number 8 of 1999 about Consumer Protection
}

\author{
Elis Herlina \\ \{elisherlina1504@gmail.com\} \\ Universitas Islam Nusantara, Indonesia
}

\begin{abstract}
In its practice, it was unilateral fiduciary security object seizure. Besides, the fiduciary security had not been registered. It literally harms consumers and does contradict with the Law Number 8 of 1999 on the Consumer Protection. This research aims to find out and review the imposition of unregistered fiduciary security from the perspective of Law Number 8 of 1999 on the Consumer Protection. This was analytical, descriptive research with normative juridical approach, while the data collection technique in use was literature research. The research result concluded that the imposition of unregistered fiduciary security has infringed the Article 2, Article 4, Article 18 clause (1) letter d, Article 18 clause (1) letter h as well as Article 18 clause (2) of the Law Number 8 of 1999 on the Consumer Protection and in this case, the financing institution may be imprisoned for 5 (five) years or charged with criminal fine amounting to Rp. 2.000.000,0 (two million rupiah) as set out under the Article 62 of Law Number 8 of 1999 on the Consumer Protection.
\end{abstract}

Keywords: fiduciary security, unregistered, consumer protection

\section{Introduction}

In Indonesia, fiduciary guarantee is regulated on Law Number 42 of 1999 about Fiduciary Guarantee. Currently, fiduciary guarantees have actually been used widely in lendingborrowing transactions since its implementation is deemed simple, easy, and quick.

To provide legal certainty, Article 11 of Fiduciary Guarantee Law requires the materials made as fiduciary guarantees to be registered in Fiduciary Registration Office located in Indonesia. The registration of the materials made as fiduciary guarantees is conducted in the domicile of a fiduciary provider, and its registration covers materials, either located inside or outside of Republic of Indonesia to meet publicity principle and serves as guarantee of certainty against other creditors regarding the materials made as fiduciary guarantees. Fiduciary guarantee registration application is conducted by a fiduciary recipient, their proxies or representatives by attaching a statement of fiduciary guarantee registration. After that, Fiduciary Registration Office records fiduciary guarantees in Book of Fiduciary List on the same date as the registration application reception date. This date is deemed as time of creation for the fiduciary guarantees. Therefore, fiduciary guarantee registration is a constitutive act which creates fiduciary guarantees [1].

Fiduciary Registration Office then issues Fiduciary Guarantee Certificate on the same date as the registration application reception date. Article 14 point (1) of Fiduciary Guarantee Certificate states the words "FOR THE SAKE OF JUSTICE ACCORDING TO THE SUPREME GOD." This certificate has executorial power equal with a court verdict having permanent legal force, which means this Fiduciary Guarantee Certificate can be directly executed / performed without trial and examination processes through court, is final in nature, 
and binds parties to conduct the verdict. If debtors fail to meet the promise, fiduciary recipients are entitled to sell the materials serving as fiduciary guarantee objects based on their own power.

In the practice, fiduciary guarantee objects are taken unilaterally, whereas the fiduciary guarantees are not registered. It really harms consumers and violates Law Number 8 of 1999 about Consumer Protection, so consumers need to be protected. It is in line with Article 1 point (1) of Law Number 8 of 1999 emphasizing that: "Consumer protection is all measures to guarantee legal certainty to provide protection to consumers."

\section{Methodology}

This is a normative juridical research, which is a research using secondary data or literary data [2] and is descriptive analysis in nature by providing overview about existing facts supported with prevailing and applicable terms [3]. Data collection technique is conducted through library research by collecting secondary data covering the materials of primary, secondary, and tertiary law. As supporting data, interviews are conducted to related parties. Then, the obtained data is analyzed using descriptive qualitative method [4].

\section{Result and Discussion}

There are two forms of fiduciary guarantee namely fidusia cum creditore and fidusia cum amico. Both arise from an agreement named pactum fiduciae which is then followed by right submission or in iure cession. In the first form or completely named fiducia cum creditore contracta, which means a promise of trust made with creditor, debtors will transfer the ownership of a material to creditors as the guarantee for their debts under an agreement that creditors will re-transfer the ownership to debtors if their debts have been repaid [1].

Referring to the content of promise agreed in form of fiducia cum creditore, there are several essential points as the elements of legal relationship between debtors and creditors, namely [5] :

1. Debtors transfer their ownership of materials to creditors.

2. The submitted materials serve as debt guarantees.

3. Physically, the materials made as debt guarantees are controlled by debtors.

4. Creditors are required to return the rights of those materials to debtors after performing their obligations.

According to Article 1 point 1 of Law Number 42 of 1999 about Fiduciary Guarantee: "Fiduciary is the transfer of ownership rights of a material based on trust under a condition that the material whose ownership rights are transferred remains in the control of the material's owner".

Article 1 number 1 of Law Number 8 of 1999 about Consumer Protection: "Consumer protection is all measures which guarantee legal certainty to provide protection to consumers". There were four basic rights consumers [6]:

1. The right to safety

2. The right to be informed

3. The right to choose

4. The right to be heard

Consumer protection law can be seen to merely set a floor in its pursuit of a sufficiently high level of consumer protection [7]. Ukwueze argued that consumer rights essentially seek to maintain human dignity and well-being in the market. Ukwueze concluded that consumer rights are evidently incorporated in human rights as there is a growing international recognition of consumer rights as human rights [8]. 
Debt collectors performing unilateral collection not only violates existing law but also consumer rights as stated on Article 4 of Law Number 8 of 1999 about Consumer Protection that consumers are entitled to convenience, security, and safety in consuming goods and/or services. Therefore, it needs clarity over the unilateral collection performed by debt collectors [9].

The agreements made between funding institutions and consumers are stated on loan agreements between consumers and funding institutions. The agreement concept has been prepared by funding institutions and consists of fixed clauses which are the terms or conditions made unilaterally and intended by binging institutions and have to be met by consumers so consumers are in a weak position as they have to follow everything which has been determined by funding institutions. Therefore, consumers have to be protected based on applicable statutory laws [10].

Therefore, funding institutions have violated consumers' rights over correct, clear, and honest information about the condition and guarantee of goods and/or services as stated on Article 4 (c) of Law Number 8 of 1999 about Consumer Protection

Funding agreements containing fixed clauses sometimes harm consumers since funding institutions do not provide explanation correctly, clearly, and honestly to consumers about the contents of agreement whose expressions are hard to understand, so it violates Article 7 (b) of Consumer Protection Law [11]. Moreover, funding institutions have to treat and serve consumers equally, not discriminatively. In making agreements, good intention (te goeder trouw) must always exist, either on consumers or funding institutions. If the consumers with good intention experience bankruptcy (fail to meet the promise), funding institutions easily charge consumers. However, if contrary situations occur, consumers will experience loss due to their weak positions in agreements. Therefore, to protect consumers' interest, funding institutions can be charged in civil basis as they have conducted bankruptcy or legal-offending actions based on Article 1365 of Civil Code or in criminal basis based on Law Number 8 of 1999 about Consumer Protection and Criminal Code [12].

Funding agreement between the funder and consumer is a standard contract since the format of the agreement has been priorly preparaed by financing institution so consumers have no longer freedom to determine form, content and condition of the agreement. The contract is made in a similar format and used in the agreement funding.

Article 18 of Consumer Protection Law makes some prohibition of stnadard clause use in contract standard. The prohibition is related to the two matters, they are content and the writing form. In terms of content, it is prohibited to use contract standard containing unfair clauses, while in terms of writing form, the clauses shall be wriitten in a simple, clear and comprehensible that it can be read and understood well by the consumers. In other words, it is aimed at placing the position of consumers are at the same level with the business person in accordance with the freedom of making contract principle and avoiding the probability of any disadvantaging acts for comsumers due to factors of ignorance, unfair position, etc. That might can be utilized by the businessperson to gain profit [13].

In the practice of consumer financing agreements, if a consumer does not pay for three months, then the finance company can take it by force, even though the consumer has signed an agreement with the finance company as the legal owner of the item, but the payment is in installment. This is contrary to Article 18 paragraph 1 letter d of Law Number 8 of 1999 concerning Consumer Protection, that businesspersons in offering products or services intended to be traded are prohibited from mentioning the standard clause in each document or agreement if it states the authorization from the consumer to the perpetrator business, both directly and indirectly, to take all unilateral actions related to products purchased by consumers in installments [14]. 
In addition, this agreement is also accompanied by a power of attorney for fiduciary binding and this is contrary to Article 18 paragraph 1 letter h of Act Number 8 of 1999 concerning Consumer Protection stating that: "Businesspersons in offering goods or services intended to be traded are prohibited include standard clauses in each document or agreement if it states that the consumer authorizes the businessperson to impose mortgage rights, liens, or collateral rights to goods purchased by consumers in installments. Financing agreements are also written in very small letters, so they are contrary to Article 18 paragraph (2) of the Consumer Protection Act. If the financing institution violates Article 18 of the Law concerning Consumer Protection, then the sanction imposed is in the form of a maximum of 5 (five) years imprisonment or a maximum fine of Rp. 2,000,000,000 (two billion rupiah) as stipulated in Article 62 of Law Number 8 of 1999 concerning Consumer Protection.

Thus, the use of standard forms containing terms and conditions that use standard clauses prohibited by Article 18 paragraph (1) of Law Number 8 of 1999 concerning financing agreements with the submission of fiduciary property rights makes the agreement null and void [15].

\section{Conclusion}

Imposing unregistered fiduciary guarantees has violated the principle of consumer protection regarding consumer safety and security as well as legal certainty as stipulated in Article 2 of Law Number 8 of 1999 concerning Consumer Protection, also has violated consumer rights as stipulated in Article 4 of the Law Number 8 of 1999. In addition, it has included standard clauses that are contrary to Article 18 paragraph (1) letter d of Law Number 8 of 1999 concerning Consumer Protection, also in contravention of Article 18 paragraph (1) letter h of Law Number 8 of 1999 concerning Consumer Protection. In addition, financing agreements use very small letters that may cause consumers to be reluctant to read them. Thus, the financing institution may be subject to sanctions for a maximum imprisonment of 5 (five) years or a maximum fine of Rp. 2,000,000,000 (two billion rupiah) as stipulated in Article 62 of Law Number 8 of 1999 concerning Consumer Protection.

\section{References}

[1] Gunawan Widjaja \& Ahmad Yani, Jaminan Fidusia, PT. Raja Grafindo Persada, p. 148, (2007).

[2] Ronny Hanitijo Soemitro, Metodologi Penelitian Hukum dan Juritmetri, Ghalia Indonesia, Jakarta, p.10, (1990).

[3] Soerjono Soekanto, Pengantar Penelitian Hukum, Universitas Indonesia Pers, Jakarta, p.86, (1986)

[4] Maria S.W. Sumardjono, Pedoman Pembuatan Usulan Penelitian, Fakultas Hukum UGM, Yogyakarta, pp. 24-25, 119, (1989)

[5] ] H. Tan Kamelo, Hukum Jaminan Fidusia Suatu Kebutuhan Yang Didambakan, Alumni, Bandung, p. 42, (2006).

[6] Mustafa 'Afifi bin Ab. Halima1, Kamilah Wati binti Mohdb Mohd Mahyeddin Mohd Sallehc, Dr. Asming Yalawaed, Tuan Syed Mohd Najib Syed Omare, Asmidah Ahmadf, Azlin Alisa binti Ahmadg, Mohd Izhar Ariff bin Mohd Kashimh, "Consumer Protection of Halal Products In Malaysia": A Literature Highlight, INHAC 2012 Kuala Lumpur International Halal Conference, PWTC, Kuala Lumpur, Malaysia, 4-5 September (2012).

[7] Dan Jerker B.Svantesson, Enter the quagmire - the complicated relationship between data protection law and consumer protection law, Computer Law \& Security Review, Vol. 34, Issue 1, p. 1, February (2018) 
[8] Indra Setiawan, "Perjanjian Kredit dengan Pembebanan Jaminan Fidusia antara Konsumen dan Lembaga Pembiayaan Non Bank (Finance)", http://indraswat.wordpress.com/2017/9/10/perjanjian-kredit-dengan -pembebanan, accessed on 5 Maret (2018).

[9] El Zahra Aulia Faradita, Suharnoko, "Perlindungan Hukum Terhadap Konsumen dalam Hal Eksekusi Jaminan Ditinjau dari Undang-Undang No. 8 Tahun 1999 Tentang Perlindungan Konsumen (Analisis Putusan No. 105/Pdt.G/2012/PN.Ska)", lib.ui.ac.id/naskahringkas/2016-05/S58005-El\%20Zahra\%20A, accessed on 3 March (2018).

[10] Juwita, "Leasing Dalam Perspektif Perlindungan Konsumen Menurut Undang-Undang No. 8 Tahun 1999 Tentang Perlindungan Konsumen”, jlps.iblam.ac.id/index.php/jurnal-hukum-dan-kebijakan/../63byS.suardi.2016, accessed on 3 Maret (2018).

[11] Sami Alsmadi1 - Ibrahim Alnawas2, "Consumer Rights Paradigm: Development of the Construct in the Jordanian Context", Journal of Business Ethics https://doi.org/10.1007/s10551-018-3815-4

[12] Kitab Undang-Undang Hukum Pidana

[13] Kitab Undang-Undang Hukum Perdata

[14] Undang-Undang Nomor 8 Tahun 1999 Tentang Perlindungan Konsumen

[15] Undang-Undang Nomor 42 Tahun 1999 Tentang Jaminan Fidusia 